Revised Manuscript for Journal of Hazardous Materials

\title{
Mechanism of Uranium Removal from the Aqueous Solution by Elemental Iron
}

Noubactep C., ${ }^{(\text {a) }}$ Schöner A., ${ }^{(b)}$ Meinrath G. ${ }^{(c, d)}$

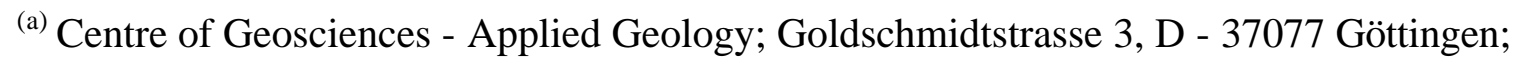

(b) Institute of Geosciences, Friedrich-Schiller-University Jena; Burgweg 11, D - 07749 Jena;

(c) Technical University Mining Academy Freiberg, Institute of Geology, G.-Zeuner-Str. 12, D

- 09596 Freiberg;

(d) RER Consultants, Schießstattweg 3a, D - 94032 Passau.

(*) corresponding author: cnoubac@gwdg.de;

Tel. +4955139 3191, Fax: +49551399379

\begin{abstract}
The effectiveness of elemental iron $\left(\mathrm{Fe}^{0}\right)$ to remove uranium $(\mathrm{U})$ from the aqueous phase has been demonstrated. While the mitigation effect is sure, discrepancies in the removal mechanism have been reported. The objective of this study was to investigate the mechanism of U(VI) removal from aqueous phases by $\mathrm{Fe}^{0}$. For this purpose a systematic sequence of bulk experiments was conducted to characterize the effects of the availability and the abundance of corrosion products on $\mathrm{U}(\mathrm{VI})$ removal. Results indicated that $\mathrm{U}(\mathrm{VI})$ removal reactions did not primary occur at the surface of the metallic iron. It is determined that $\mathrm{U}(\mathrm{VI})$ co-precipitation with aging corrosion products is a plausible explanation for the irreversible fixation under experimental conditions. Results of XRD analyses did no show any U phases, whereas SEMEDX analyses showed that $\mathrm{U}$ tended to associate with rusted areas on the surface of $\mathrm{Fe}^{0}$. Recovering U with different leaching solutions varied upon the dissolution capacity of the individual solutions for corrosion products, showing that the irreversibility of the removal
\end{abstract}


depends on the stability of the corrosion products. $\mathrm{U}(\mathrm{VI})$ co-precipitation as removal mechanism enables a better discussion of reported discrepancies.

Key Words: co-precipitation, elemental iron, mechanism, removal, uranium.

\section{Introduction}

Groundwater at some contaminated sites has uranium-contents up to $50 \mathrm{mg} / \mathrm{L} \cdot{ }^{[1-3]}$ This value is more than 1600 times larger than the US EPA threshold value of $30 \mu \mathrm{g} / \mathrm{L}$. Therefore efficient, applicable and affordable techniques are necessary to mitigate the health risk by eliminating or reducing the removal of $\mathrm{U}$ from the mine water and contami nated groundwater. Elemental iron $\left(\mathrm{Fe}^{0}\right)$, widely termed in the literature on permeable reactive barriers as zerovalent iron, has been discussed as an U-removing reagent. ${ }^{[4,5]}$ To be effective in the long term, any remediation technique for $\mathrm{U}$ must target both mobile aqueous $\mathrm{U}(\mathrm{VI})$-species and $\mathrm{U}(\mathrm{VI})$-precipitates that may be long term sources. Therefore, remediation with $\mathrm{Fe}^{0}$ that possibly reduces mobile $\mathrm{U}(\mathrm{VI})$ aqueous species to less soluble $\mathrm{U}(\mathrm{IV})$ precipitates is very promising. ${ }^{[6]}$ Furthermore, elemental iron could maintain reducing conditions in the subsurface, under which other electron donors besides $\mathrm{Fe}^{0}$ (e.g. organics) may also contribute to $\mathrm{U}(\mathrm{VI})$ reduction.

Several U(VI) reduction methods for groundwater remediation have been proposed including application of $\mathrm{Fe}^{0},{ }^{[4,6,7]}$ application of mixed ferrous/ferric iron hydroxides, ${ }^{[8-12]}$ and bioreduction. ${ }^{[13,14,15]}$

Information regarding the mechanism of $\mathrm{U}(\mathrm{VI})$ removal by $\mathrm{Fe}^{0}$ is confusing and even conflicting. ${ }^{[16-18]}$ For example Cantrell et al.${ }^{[4]}$ used thermodynamic calculations to predict reduction of $\mathrm{U}(\mathrm{VI})$ to $\mathrm{U}(\mathrm{IV})$ not only as a possible, but also as eventual dominant reaction pathway. This conclusion was experimentally supported by Abdelouas et al.. ${ }^{[19]}$ Farrell et al., ${ }^{[7]} \mathrm{Gu}$ et al.${ }^{[6]}$ Based on the paper of Gu et al.$^{[6]}$ a clear trend for "reductive precipitation of 
$\mathrm{U}(\mathrm{VI})$ by $\mathrm{Fe}^{0,}$, can be observed in the recent literature. ${ }^{[18,20-24]}$ However, the initial experimental conditions of these authors were not adequate for appropriate conclusions. ${ }^{[16,25]}$ Moreover, available field data are not consistent with quantitative $\mathrm{U}(\mathrm{VI})$ reduction by $\mathrm{Fe}^{0}{ }^{[20}$, ${ }^{26]}$ On the other hand, Morrison et al. ${ }^{[22]}$ stated that no U(IV)-phases were reported, whereas Abdelouas et al. ${ }^{[19]}$ reported the identification of poorly crystallized $\mathrm{UO}_{2(\mathrm{~s})}$. Note that Cui \& Spahiu ${ }^{[27]}$ reported $\mathrm{U}(\mathrm{VI})$ reduction to $\mathrm{UO}_{2(\mathrm{~s})}$ on the top of green rust (a corrosion product), whereas from the works of Behrends and Van Cappellen ${ }^{[11]}$, Charlet et al. ${ }^{[8]}$, Jeon et al. ${ }^{[12]}$, and Liger et al. ${ }^{[9]}$ it is evident that $\mathrm{Fe}^{0}$ may serve as a source of $\mathrm{Fe}(\mathrm{II})$ for an abiotic $\mathrm{U}$ removal process involving structural $\mathrm{Fe}(\mathrm{II})\left[\mathrm{Fe}^{2+}{ }_{(\mathrm{s})}\right]$ at the surface corrosion products. In contrast, Qiu et al. ${ }^{[28]}$ experimentally observed no reduction of U(VI) to U(IV) under anoxic conditions. This result was supported by Bostick et al. ${ }^{[29]}$ and Fiedor et al. ${ }^{[30]}$ Fiedor et al. ${ }^{[30]}$ explained the absence of reduction with the fact that the purging mixture to maintain anoxic conditions contained $\mathrm{CO}_{2}$. This $\mathrm{CO}_{2}$ (dissolved $\mathrm{HCO}_{3}{ }^{-}$or $\mathrm{CO}_{3}{ }^{2-}$ ) forms stable complexes with $\mathrm{U}(\mathrm{VI})$ and favors its remaining in the bulk solutions. On the other hand, Qiu et al. ${ }^{[28]}$ carefully characterized the reacted iron surface with scanning tunneling microscopy and X-ray photoelectron spectroscopy and concluded that "under certain conditions, $\mathrm{Fe}^{0}$ can remove contaminants effectively without reduction". Note that Qiu et al. ${ }^{[28]}$ also noticed that an extremely thick U(VI) film was formed in the absence of $\mathrm{CO}_{2}$, when the reaction took place in a $\mathrm{N}_{2}$-purged solution. The importance of $\mathrm{CO}_{2}$-availability for the removal of $\mathrm{U}(\mathrm{VI})$ by $\mathrm{Fe}^{0}$ was not further investigated and indicates that sorption may play an important role in this removal process, because $\mathrm{CO}_{2}$-availability could avoid $\mathrm{U}(\mathrm{VI})$ accumulation at the surface of $\mathrm{Fe}^{0}$.

In a reactive barrier, $\mathrm{U}(\mathrm{VI})$ removal will be the result of a competition between at least three possible processes: (1) $\mathrm{U}(\mathrm{VI})$ reduction by $\mathrm{Fe}^{0}$ and certain corrosion products [including structural Fe(II) and green rust]; (2) U(VI) adsorption onto in situ generated iron corrosion products; and (3) U(VI) incorporation in the structure of ageing corrosion products (co- 
precipitation). Therefore, it is very difficult to resolve the effect of specific redox reactions on U(VI) removal from the effects of other processes. Fortunately, a systematic sequence of bulk reactions can quench one process or the other. For example acidification to values $<\mathrm{pH} 5$ will minimize adsorption and co-precipitation. Under these conditions, U(VI) removal should mostly result from $\mathrm{Fe}^{0}$ reduction. Similarly, controlled dissolution of corrosion products after U(VI) removal may give some insights on the mechanism of its retention. Therefore, a variety of reactions (sorption, desorption, acidic or reductive dissolution, and iron oxide dissolution through complex formation) can be undertaken to improve the understanding of the interactions of $\mathrm{U}(\mathrm{VI})$ with $\mathrm{Fe}^{0}$ in the aqueous solution.

The objectives of this study were to elucidate the mechanism of U(VI) removal from aqueous solution by $\mathrm{Fe}^{0}$ in three steps:

- by characterizing the role of $\mathrm{Fe}^{0}$ in $\mathrm{U}(\mathrm{VI})$ removal from an aqueous solution;

- by characterizing the effect of availability and reactivity of iron corrosion products on $\mathrm{U}(\mathrm{VI})$ removal;

- by conducting remobilization experiments with different leaching solutions.

For this purpose, batch experiments were carried out without mixing (stirring or agitating) the solutions with a constant amount of a well-characterized $\mathrm{Fe}^{0}$ and fixed amounts of two known natural $U$ adsorbents: pyrite mineral, $\mathrm{FeS}_{2}$ (in two different fractions: $\mathrm{d}_{1}$ and $\mathrm{d}_{2}$ ) and manganese nodules, $\mathrm{MnO}_{2}$. Leaching experiments were conducted with sodium carbonate (0.1 M), EDTA (0.01 M), hydrochloric acid $(0.2 \mathrm{M})$ and $\mathrm{TiCl}_{3}(1.25 \%)$. The initial U(VI) concentration was $0.084 \mathrm{mM}(20 \mathrm{mg} / \mathrm{L})$ and the solid:solution ratio was $5 \mathrm{~g} / \mathrm{L}$ for $\mathrm{Fe}^{0}$ and $\mathrm{MnO}_{2}$ and $15 \mathrm{~g} / \mathrm{L}$ for $\mathrm{FeS}_{2}$ respectively.

\section{Theoretical Background on the applied methodology}

The uncertainty on uranium removal mechanism by $\mathrm{Fe}^{0}$ (adsorption, co-precipitation or reduction) is a controversial issue for the scientific community. ${ }^{[16,20,21,26]}$ Initially, it was 
believed that $\mathrm{U}(\mathrm{VI})$ would be removed by reductive precipitation. ${ }^{[4,6]}$ The reduced form of $\mathrm{U}$ is less soluble and would provide the longest and safest long-term immobilization. However, published studies suggested that a significant portion of the $\mathrm{U}$ removed by $\mathrm{Fe}^{0}$ would remain in the oxidized form. ${ }^{[7,16,20,26,28,30-32]}$ At present, these evidently contradictory results have not been discussed.

Table 1 summarizes the possible involved mechanisms for the U removal. Among the listed mechanisms, the formation of uranyl-hydroxy compounds such as schoepite $\left(\mathrm{UO}_{3} \cdot 2 \mathrm{H}_{2} \mathrm{O}\right)$ has not been discussed, even though many studies have used over-saturated U(VI)-solutions with respect to schoepite. ${ }^{[16]}$ This is particularly important in the neutral $\mathrm{pH}$ range when the $\mathrm{U}$ concentration is above $10^{-5} \mathrm{M}$ and a $\mathrm{pH}$-shift can occur during the reaction. Reductive precipitation is the most suitable reaction pathway and has been considered for some years as a primary reaction mechanism. Surface catalysed U(VI) reduction by structural $\mathrm{Fe}(\mathrm{II})\left[\mathrm{Fe}^{2+}{ }_{(\mathrm{s})}\right]$ has also been reported (Eq. iv, ref. 8, 9, 11 and 12).

Table 2 summarizes some relevant reactions for the elucidation of the mechanism of U(VI) fixation by $\mathrm{Fe}^{0}$ in this work. U(VI) removal is supposedly based on electrochemical corrosion of iron resulting in "reductive precipitation" of U(VI) according to Eq. 1 (Eq. iii in table 1). $\mathrm{U}(\mathrm{VI})$ can be reduced to U(IV) by structural Fe(II) (Eq. 2). Iron corrosion also produces molecular hydrogen $\left(\mathrm{H}_{2}\right)$ which is capable of chemically reducing U(VI) (Eq. 3). Therefore, establishing a reductive atmosphere by adding molecular $\mathrm{H}_{2}$ (gas) is to be avoided when investigating possible reduction of $\mathrm{U}(\mathrm{VI})$ to $\mathrm{U}(\mathrm{IV})$. Thermodynamically, $\mathrm{H}_{2}$ is capable of chemically reducing $\mathrm{U}(\mathrm{VI})$ to $\mathrm{U}(\mathrm{IV})$ and since it is a gas, the reduction can occur even if $\mathrm{U}(\mathrm{VI})$ is sorbed onto the $\mathrm{Fe}^{0}$ surface (non-electrochemical mechanism). In the present study, no attempt has been made to control more parameters than in previous works. ${ }^{[16]}$ The detailed conditions in a reactive barrier based on $\mathrm{Fe}^{0}$ will certainly vary over its lifetime. In particular, it can not be expected that strictly anoxic conditions will prevail in the majority of reactive walls because they are installed at depths not greater than $15-22 \mathrm{~m}\left(50-70\right.$ feet deep). ${ }^{[34]}$ 
In the presence of an oxidant (molecular $\mathrm{O}_{2}$ or $\mathrm{MnO}_{2}$ ), $\mathrm{Fe}^{2+}$ formed from Eq. 1 will be oxidized to $\mathrm{Fe}^{3+}$. If dissolved $\mathrm{Fe}^{3+}$ is present, $\mathrm{UO}_{2}$ (resulting from Eq. 1, 2 or 3) can be reoxidized according to Eq. 4, yielding dissolved $\mathrm{Fe}^{2+}$ and U(VI). This potential re-oxidation of $\mathrm{UO}_{2}$ by $\mathrm{Fe}^{3+[35]}$ is often ignored in the reactive barrier literature. ${ }^{[16]}$ Since the solubility of $\mathrm{Fe}^{3+}$ is very low in the neutral $\mathrm{pH}$ range, it will precipitate as $\mathrm{Fe}(\mathrm{OH})_{3}$ and other secondary minerals (Eqs $5 \& 6$ ). In the presence of pyrite, there will be a competition (between pyrite and $\mathrm{UO}_{2}$ ) for $\mathrm{Fe}^{3+}$, see Eq. 7 (cf. Eq. 4). Hence, $\mathrm{Fe}^{3+}$ is not available to oxidize $\mathrm{UO}_{2}$, and $\mathrm{U}(\mathrm{VI})$ concentration remains low. On the other hand, pyrite can reduce $\mathrm{U}(\mathrm{VI})$ yielding $\mathrm{UO}_{2}$ precipitation according to Eq. 8 .

Equation 9 illustrates the effect of manganese nodules $\left(\mathrm{MnO}_{2}\right)$ as $\mathrm{Fe}^{2+}$-scavenger and potential accelerator of $\mathrm{Fe}^{0}$ corrosion. If this is the case, and the mechanism of U(VI) removal by $\mathrm{Fe}^{0}$ is "reductive precipitation", $\mathrm{U}(\mathrm{VI})$ removal will be accelerated by the presence of $\mathrm{MnO}_{2}$ (assumption 1). Equation 10 shows that $\mathrm{Ti}^{3+}$ is capable of inducing reductive dissolution of iron oxide and Eq. 11 shows that EDTA can dissolve iron oxides by complexing $\mathrm{Fe}^{3+}$ ions. In both cases it is essential that, if $\mathrm{U}$ is retained (at least in part) by adsorption onto iron oxides, their dissolution will release $\mathrm{U}$ in the aqueous solution (assumption 2). Finally as illustrated by Eqs $5 \& 7$, the addition of pyrite to a system can induce a $\mathrm{pH}$ decrease $\left(\mathrm{H}^{+}\right.$production), which is known to increase $\mathrm{U}$ solubility (Eq. $\mathrm{i}$ in table $1)$.

In the presence of $\mathrm{Fe}^{0}$ (covered by corrosion products) and pyrite, reactions 1 to 8 are possible. U(VI) removal should be governed principally by reductive precipitation. If the reaction vessel is closed, the acidification reaction due to Eq. 5 or pyrite oxidation through molecular $\mathrm{O}_{2}$ will be limited. The removal of $\mathrm{U}(\mathrm{VI})$ from the aqueous solution can be due to each of the mechanisms from table 1: (a) U(VI) reduction by $\mathrm{Fe}^{0}$, structural $\mathrm{Fe}(\mathrm{II})$ and/or $\mathrm{FeS}_{2}$ (Eqs 1, 2 and 8); (b) sorption onto the surface of-- $\mathrm{Fe}^{0}, \mathrm{FeS}_{2}$ or onto iron corrosion products, and (c) formation of uranyl-hydroxy compounds. 
Reductive precipitation through $\mathrm{Fe}^{0}$ is more favored when the surface of the material is not covered by corrosion products (especially around $\mathrm{pH} 4$ ) and sorption onto iron corrosion products (iron oxides) occurs favorably at $\mathrm{pH}>5$ (assumption 3). Thus, combining $\mathrm{Fe}^{0}$ and limited amounts of $\mathrm{FeS}_{2}$ into closed vessels is a suitable way to investigate the mechanism of U(VI) removal by both materials. It is expected that various experimental durations will yield various final $\mathrm{pH}$ values, thereby permitting the characterization of the impact of corrosion products on the removal process, especially their reactivity.

Similarly, combining $\mathrm{Fe}^{0}$ and limited amounts of $\mathrm{MnO}_{2}$ into closed vessels is a suitable way to investigate the influence of the availability of corrosion products on the process of U(VI) removal by $\mathrm{Fe}^{0}$. Finally, adding $\mathrm{HCl}-, \mathrm{Ti}^{3+}$ - and/or EDTA-solutions (or $\mathrm{FeS}_{2}$-grains to induce a $\mathrm{pH}$-shift) to a system consisting of $\mathrm{U}(\mathrm{VI})$ and $\mathrm{Fe}^{0}$, which have reacted for a suitable period, is a suitable way to investigate the role of acidic, complexive, or reductive dissolution of iron oxides on the fate of fixed uranium, and therefore to deduce the mechanism of their initial fixation.

\section{Experimental Section}

\subsection{Materials}

The used scrap iron was selected from 13 materials because of its reactivity after the EDTAtest. $^{[36,37]}$ The material contained apart from iron about $3.5 \% \mathrm{C}, 2 \% \mathrm{Si}, 1 \% \mathrm{Mn}$, and $0.7 \%$ Cr. The material was crushed and the size fraction 1.0-2.0 $\mathrm{mm}$ was used without further pretreatment. $\mathrm{Fe}^{0}$ was used as $\mathrm{U}(\mathrm{VI})$ reducing agent.

Manganese nodules from the deep sea were crushed and sieved. An average particle size of $1.5 \mathrm{~mm}$ was used comprising the following elemental composition: $41.8 \% \mathrm{Mn}, 2.40 \% \mathrm{Fe}$, $2.41 \% \mathrm{Si}, 0.74 \% \mathrm{Ni}, 0.22 \% \mathrm{Zn}, 1.39 \% \mathrm{Ca}$, and $0.36 \% \mathrm{Cu}$. The target active component is $\mathrm{MnO}_{2} \cdot \mathrm{MnO}_{2}$ is a $\mathrm{Fe}^{2+}$-scavenger, supporting iron corrosion and retarding the availability of "free" corrosion products in the bulk. 
Pyrite was crushed and sieved. The fractions $0.2-0.315 \mathrm{~mm}\left(\mathrm{~d}_{1}\right)$ and $0.315-0.63 \mathrm{~mm}\left(\mathrm{~d}_{2}\right)$ were used. The elemental composition was $40 \% \mathrm{Fe}, 31.4 \% \mathrm{~S}, 6.7 \% \mathrm{Si}, 0.5 \% \mathrm{Cl}, 0.15 \% \mathrm{C}$, and < $0.01 \% \mathrm{Ca}$. The material served as a $\mathrm{pH}$-shifting reagent, modifying the reactivity of corrosion products and the solubility of $\mathrm{U}(\mathrm{VI})$, hence inhibiting the precipitation of iron oxides at the surface of $\mathrm{Fe}^{0}$.

Water works sludge (WWS) is typically a mixture of iron and manganese oxides, the detailed composition depending on the composition of the treated water. WWS from the Torgau water treatment plant (Saxonia, Germany) with a low content of $1.09 \% \mathrm{Mn}(43.9 \% \mathrm{Fe}, 6.2 \% \mathrm{Ca}$, $5.42 \% \mathrm{Si}$ ) was used as $\mathrm{U}(\mathrm{VI})$ adsorbent simulating aged corrosions products.

The used apatite was crushed and sieved, an average particle size of $1.5 \mathrm{~mm}$ was used with the following elemental composition: $26.7 \% \mathrm{P}, 36.8 \% \mathrm{Ca}, 0.83 \% \mathrm{Fe}, 0.72 \% \mathrm{Si}$, and $0.13 \%$ S. Apatite (a phosphate mineral) was used to remove dissolved U(VI) by adsorption or/and by the formation of low soluble phases. ${ }^{[38,39]}$

\subsection{Fixation Experiments, Desorption with $\mathrm{Na}_{2} \mathrm{CO}_{3}$ and Analytical Method}

The experimental procedure for the fixation experiments, the desorption by $0.1 \mathrm{M} \mathrm{Na}_{2} \mathrm{CO}_{3}$ and the analytical method is described in detail elsewhere, ${ }^{[16]}$ and will not be repeated here. Unless indicated otherwise, fixation studies consisted in three different non-shaken experiments with $5 \mathrm{~g} / \mathrm{L} \mathrm{Fe}^{0}, 5 \mathrm{~g} / \mathrm{L} \mathrm{MnO}_{2}$ and $15 \mathrm{~g} / \mathrm{L} \mathrm{FeS}_{2}:$ I) $\mathrm{Fe}^{0}$ alone (reference system); II) $\mathrm{Fe}^{0}+\mathrm{MnO}_{2}$; and III) $\mathrm{Fe}^{0}+\mathrm{FeS}_{2}$ (termed as systems I, II and III). $\mathrm{Fe}^{0}$ and additives were allowed to react in sealed sample tubes containing $20.0 \mathrm{~mL}$ of an U(VI) solution $(20 \mathrm{mg} / \mathrm{L}$ or $0.084 \mathrm{mM})$ at laboratory temperature (about $22^{\circ} \mathrm{C}$ ). The experimental duration varied from 14 to 150 days. The tubes $(16 \mathrm{~mL}$ graded) were filled to the total volume $(20 \mathrm{~mL})$ to reduce the head space in the reaction vessels. The contact vessels were allowed to equilibrate in darkness to avoid photochemical side reactions, the initial $\mathrm{pH}$ was $\sim 6.6$. Desorption experiments were conducted in a $0.1 \mathrm{M} \mathrm{Na}_{2} \mathrm{CO}_{3}$ solution for $14 \mathrm{~h}$. Analysis for $\mathrm{U}$ was performed after reduction 
to U(IV) with the ArsenazoIII method (detection limit: $25 \mu \mathrm{g} / \mathrm{L}) .{ }^{[40,41]}$ Analysis for dissolved ferrous iron and total iron was determined using FerroVer iron reagent (HACH DR/2000 Spectrophotometer Handbook, Loveland, CO). The experiments were performed in triplicates. The mean values are presented in the figures.

The experiments were conducted in closed essay tubes under non-controlled $\mathrm{O}_{2}\left(\right.$ and $\left.\mathrm{CO}_{2}\right)$ pressure. It is certain that $\mathrm{P}_{\mathrm{O} 2}$ was less than the atmospheric pressure. It can be assumed that $\mathrm{U}(\mathrm{VI})$ removal mainly occurred under very low $\mathrm{O}_{2}$ partial pressure, since iron corrosion (and pyrite dissolution) is $\mathrm{O}_{2}$ consuming. ${ }^{[42]}$ Since strictly anoxic conditions are not expected in the majority of $\mathrm{Fe}^{0}$ reactive walls, ${ }^{[34]}$ working at low oxygen level $\left(\mathrm{P}_{\mathrm{O} 2}<\mathrm{P}_{\mathrm{O} 2 \text {, atm }}\right.$ and $\left.\mathrm{P}_{\mathrm{O} 2} \neq 0\right)$ is probably a good simulation for groundwater situations at several sites.

\subsection{Remobilization Experiments with pyrite, EDTA, $\mathrm{HCl}, \mathrm{TiCl}_{3}$ and Ti-EDTA}

Prior fixation experiments were conducted for two months; then uranium remobilization occurred for 14 hours through addition of defined amounts of additives: pyrite (1g, two different particle sizes), EDTA $(0.01 \mathrm{M}), \mathrm{HCl}(0.2 \mathrm{M}), \mathrm{TiCl}_{3}(1.25 \%)$ and a mixture of EDTA $(0.01 \mathrm{M})$ and $\mathrm{TiCl}_{3}(1.25 \%)$. The selection of these reactants and their concentrations were motivated by literature data from Ford ${ }^{[43]}$ and Heron et al. ${ }^{[44]}$

\subsection{X-Ray diffraction and SEM analyses}

The corrosion products of $\mathrm{Fe}^{0}$ were identified by X-ray diffraction (XRD) analyses. Samples were prepared by retrieving iron fillings with a magnetic bar and filtering the suspended particles from the mixture of $\mathrm{Fe}^{0}$ and $\mathrm{U}(\mathrm{VI})$ solution under laboratory conditions. The samples were then dried under laboratory conditions and pulverized for XRD analyses at the Institute of Physical Chemistry of the University of Freiberg. Under these experimental conditions, partial transformations of iron (oxyhydr)oxides and reoxidation of U(IV) by air oxygen are possible. $^{[45]}$ 
Coupons of the same $\mathrm{Fe}^{0}$ material (> $2.5 \mathrm{~mm}$ ) were pre-washed for 14 hours in $0.2 \mathrm{M} \mathrm{HCl}$ and allowed to react in the identical way as the fillings. Scanning electron microscope (SEM) and Energy Dispersive Spectroscopy (EDS) of the coupons were conducted to examine the distribution of iron corrosion products and $\mathrm{U}$ coatings on $\mathrm{Fe}^{0}$ at the Institute of Geology of the University of Freiberg.

\section{Results and Discussion}

The experiments were compared on the basis of the total fixation $\mathrm{P}_{\text {tot }}($ in $\%$ ) defined by Eq. 13

$$
\mathrm{P}_{\text {tot }}=100 \% *\left(1-\left(\mathrm{C} / \mathrm{C}_{0}\right)\right)
$$

where $\mathrm{C}_{0}$ is the initial concentration of uranium in solution, while $\mathrm{C}$ gives the uranium concentration after the experiment. The percent recovery, $\mathrm{P}_{\text {rec }}$, of uranium after finishing the experiment (recovery with $0.1 \mathrm{M} \mathrm{Na}_{2} \mathrm{CO}_{3}, 0.1 \mathrm{M} \mathrm{HCl}, 0.01 \mathrm{M}$ EDTA, TiCl 3 , TiEDTA or $\mathrm{FeS}_{2}$ ) is calculated by Eq. (14)

$$
P_{r e c}=100 \% \frac{C_{0}\left(V_{0}-V_{1}\right)}{V_{0}\left(C_{0}-C\right)}
$$

where $\mathrm{V}_{0}$ gives the initial volume, and $\mathrm{V}_{1}$ the volume after removing about $13 \mathrm{~mL}$ for uranium analysis.

\subsection{Evidence of progressive U(VI) removal in the presence of $\mathrm{Fe}^{0}$}

Figure 1 compares three fixation curves of U(VI) removal from aqueous solution by WWS, apatite and $\mathrm{Fe}^{0}$. While physical adsorption is the major mechanism responsible for uranium removal by WWS, both adsorption and precipitation can remove U(VI) in experiments with apatite (chemical precipitation) and $\mathrm{Fe}^{0}$ ("reductive precipitation"). As shown on Fig. 1, adsorption onto WWS (aged corrosion products) and adsorption or chemical precipitation by apatite $\left(\mathrm{aO}_{4}{ }^{3-}\right.$ bearing mineral) are relatively rapid and are achieved within the three first days of contact. U(VI) removal through $\mathrm{Fe}^{0}$ was also effective but slow and still continued 
even after 50 days. Since the reaction vessels were not shaken, U(VI) removal by $\mathrm{Fe}^{0}$ can be the result of U(VI) adsorption onto progressively generated corrosion products or the result of a slow electrochemical reduction through $\mathrm{Fe}^{0}$. Shaking the reaction vessels would have yielded a rapid production of corrosion products and their removal from the $\mathrm{Fe}^{0}$ surface, keeping the surface free for eventual "reductive precipitation". ${ }^{[46]}$ However, it is the aim of this study to characterize the role of corrosion products present at the surface of $\mathrm{Fe}^{0}$ as it will be the case in subsurface reactive walls. ${ }^{[37]}$

The major conclusion from Fig. 1 is qualitative: aged corrosion products can rapidly remove $\mathrm{U}(\mathrm{VI})$ from the aqueous solution; this reaction has been recognized for years. ${ }^{[47-49]} \mathrm{U}(\mathrm{VI})$ sorbed onto aged corrosion products can be readily recovered (desorption) in a $0.1 \mathrm{M} \mathrm{Na}_{2} \mathrm{CO}_{3}$ solution. ${ }^{[16,50]}$ The observed progressive U(VI) removal using $\mathrm{Fe}^{0}$ over a long period validates the efficiency of the chosen experimental conditions (non-shaken batch experiments) to elucidate the mechanism of $\mathrm{U}(\mathrm{VI})$ removal from aqueous solutions by $\mathrm{Fe}^{0}$. The experiments described consecutively target better characterization of progressive U(VI) removal by $\mathrm{Fe}^{0}$.

\subsection{Effect of the presence of $\mathrm{MnO}_{2}$ and $\mathrm{FeS}_{2}$ on $\mathrm{U}(\mathrm{VI})$ removal by $\mathrm{Fe}^{0}$}

A popular hypothesis to rationalize irreversible fixation of $\mathrm{U}(\mathrm{VI})$ by $\mathrm{Fe}^{0}$ is the $\mathrm{U}(\mathrm{VI})$ reduction to less soluble U(IV) species or "reductive precipitation". ${ }^{[6,7,21,24]}$ Shortcomings in the applied experimental procedures have been discussed. In particular, starting $\mathrm{pH}$ and total initial $\mathrm{U}$ concentration indicate that precipitation phenomena may have spoiled the reported results. ${ }^{[16]}$ Furthermore, the authors have conducted shaken batch experiments for periods varying from few hours to few days. A reactive barrier is however expected to work for decades. It is therefore important to conduct laboratory experiments for longer times (here up to 150 days) to better characterize the interaction between $\mathrm{U}(\mathrm{VI}), \mathrm{Fe}^{0}$ and corrosion products. In the present study and related works, ${ }^{[16,50,51]}$ two natural materials $\left(\mathrm{MnO}_{2}\right.$ and $\left.\mathrm{FeS}_{2}\right)$ were 
employed to modify the behavior of the reference system consisting of U(VI) and $\mathrm{Fe}^{0}$ in tap water of the city of Freiberg (Saxony, Germany).

The results of $\mathrm{U}$ fixation and recovery in $0.1 \mathrm{M} \mathrm{Na}_{2} \mathrm{CO}_{3}$ were given by Noubactep et al. ${ }^{[16]}$ Two main observations were made from the fixation experiments: (1) the best fixation rate is achieved when $\mathrm{Fe}^{0}$ is present alone (system I) and the least efficient was system III $\left(\mathrm{Fe}^{0}+\right.$ $\left.\mathrm{FeS}_{2}\right)$; (2) system II $\left(\mathrm{Fe}^{0}+\mathrm{MnO}_{2}\right)$ is a delayed reproduction of system $\mathrm{I}\left(\mathrm{Fe}^{0}\right.$ alone $)$. The first observation suggests that the dominant mechanism of the U(VI) removal from the aqueous phase is not "reductive precipitation" because neither assumption 1 (favor U(VI) reduction through $\mathrm{MnO}_{2}$ addition) nor assumption 3 (favor $\mathrm{U}(\mathrm{VI})$ reduction through $\mathrm{FeS}_{2}$ addition) is verified. The second observation suggests that the availability of "free" corrosion products influences the efficiency of U(VI) removal by $\mathrm{Fe}^{0}$. This hypothesis was confirmed by varying the amount of $\mathrm{MnO}_{2} \cdot{ }^{[50]}$ The results showed that the larger the amount of $\mathrm{MnO}_{2}$, the lesser the U(VI) fixation efficiency for the same experimental duration. The major conclusion from fixation experiments is that the presence and the amount of corrosion products influence $\mathrm{U}(\mathrm{VI})$ removal by $\mathrm{Fe}^{0}$.

To investigate the effect of reactivity of the corrosion products on the removal process, the $\mathrm{pH}$ was varied by varying the contact time with pyrite (system III), attending various dissolution/oxidation rates. The result shows that $\mathrm{U}(\mathrm{VI})$ removal was considerably retarded (starting 40 days after the beginning of the experiment) and that the fixation efficiency first decreased with decreasing $\mathrm{pH}$. Then $\mathrm{U}(\mathrm{VI})$ removal increased rapidly between day 40 and day 90 practically at constant $\mathrm{pH}$. The final $\mathrm{pH}$ was below 5; therefore a quantitative adsorption onto the surface of iron corrosion products was not likely. A thoroughly discussion of this experiment is given elsewhere. ${ }^{[51]}$ It was shown that $\mathrm{U}(\mathrm{VI})$ removal is accompanied by a decrease of iron concentration. This result is supported by the $\mathrm{pH}$ dependency of iron speciation. $\mathrm{Fe}^{2+}$ species are more soluble than $\mathrm{Fe}^{3+}$ species, which undergo appreciable hydrolysis in aqueous solutions to form $\mathrm{Fe}_{\mathrm{x}}(\mathrm{OH})_{\mathrm{y}}{ }^{(3 \mathrm{x}-\mathrm{y})}$. As the solution $\mathrm{pH}$ increases, the ferric 
state is stabilized relative to the ferrous state because of the higher affinity of $\mathrm{Fe}^{3+}$ for the hydroxide ion relative to $\mathrm{Fe}^{2+} \cdot{ }^{[52]} \mathrm{U}(\mathrm{VI})$ is then entrapped in the mass of these precipitating hydroxides according to the schematic reaction:

$n \mathrm{Fe}_{\mathrm{x}}(\mathrm{OH})_{\mathrm{y}}{ }^{(3 \mathrm{x}-\mathrm{y})}+\mathrm{UO}_{2}^{2+} \Rightarrow \mathrm{UO}_{2}\left[\mathrm{Fe}_{\mathrm{x}}(\mathrm{OH})_{\mathrm{y}}^{\left({ }^{(3 x-y)}\right.}\right]_{\mathrm{n}}{ }^{2+}$

Beside the $\mathrm{pH}$ values, the iron and $\mathrm{U}$ concentrations, the Eh values and the iron speciation were measured in system III, where variations were expected owing to the evolved possible reactions (Eqs 1 to 4 and Eqs 7, 8 - Tab. 2). Because of the limited volume of samples the solution parameters ( $\mathrm{pH}$ and $\mathrm{Eh}$ ) were measured once for each triplicate 24 hours after the end of the fixation experiment. The results showed a decreasing Eh value with increasing experimental duration. ${ }^{[51]}$ This observation is consistent with the fact that both iron corrosion and pyrite oxidation consume oxygen and care for low $\mathrm{O}_{2}$ level. This observation was also confirmed by the iron speciation. In fact, the solutions still contained more that $50 \%$ ferrous iron $\left(\mathrm{Fe}^{2+}\right)$ even though the speciation was not performed immediately at the end of the experiment and no attempt was made to protect the vessels from air oxygen. Therefore, air oxygen would have oxidized a considerable part of $\mathrm{Fe}^{2+}$ during this time (24 h). To access the reversibility of the $U$ fixation, desorption experiments were conducted with 0.1 $\mathrm{M} \mathrm{Na}_{2} \mathrm{CO}_{3}{ }^{[16]}$ The results showed that $\mathrm{P}_{\text {rec }}$ was comparatively high during the first 25 days for system I and system II. Afterwards, $\mathrm{P}_{\mathrm{rec}}$ decreased steadily and was almost zero for both systems after 125 days. In system III $\left(\mathrm{Fe}^{0}+\mathrm{FeS}_{2}\right)$, the fixation was nearly irreversible during the whole experiment. This is not surprising because $\mathrm{U}(\mathrm{VI})$ removal is accompanied by iron precipitation. U(VI) was therefore enclosed in the matrix of precipitating iron oxides and was not available for desorption with $\mathrm{Na}_{2} \mathrm{CO}_{3}$. The co-precipitation reaction of $\mathrm{U}(\mathrm{VI})$ with iron oxides was well described in another context by Dodge et al. ${ }^{[53]}$, Duff et al. ${ }^{[54]}$, and Eng et al. ${ }^{[55]}$ The extent of U(VI) co-precipitation by corrosion products of carbon steel was thoroughly characterized by another research group. ${ }^{[33,55]}$ These authors also report about a differential recovery efficiency of surface-sorbed and co-precipitated U(VI). Particularly, for 
maghemite, magnetite and goethite, U(VI) species were associated as oxyhydroxide species and were readily dissolved in concentrated $\mathrm{HCl}$ solution, but for lepidocrocite and ferrihydrite U(VI) species formed a bidentate complex with iron, which resisted acidic dissolution. ${ }^{[53]}$ Both U(VI) and U(IV) are soluble in $\mathrm{Na}_{2} \mathrm{CO}_{3} \cdot{ }^{[56]}$ Hence, this observation can only be explained by formation of amorphous aged iron corrosion products enclosing $\mathrm{U}$ since corrosion products are not soluble in carbonate solution. Therefore, it was concluded that the $\mathrm{U}(\mathrm{VI})$ removal was the result of the co-precipitation of $\mathrm{U}(\mathrm{VI})$ with aging corrosion products.

\subsection{Arguments for U(VI) co-precipitation with aging corrosion products}

Reported experiments for elucidating the mechanism of U(VI) removal by $\mathrm{Fe}^{0}$ have been mostly conducted under shaken or stirred conditions. These experimental tools are sometimes suitable for adsorption experiments, in which no reaction between tested materials and water is expected, respectively as long as the tested material is not broken down (into small pieces) during the experiment. ${ }^{[57,58]}$ In the case of $\mathrm{Fe}^{0}$, however, aqueous iron corrosion is well known and documented for more than one century. ${ }^{[59-62]}$ Therefore, shaking the reaction vessels causes intensive iron corrosion, thereby producing more corrosion products. ${ }^{[63]}$ On the other hand, shaking continuously frees corrosion products from the iron surface, potentially making the surface available for $\mathrm{U}(\mathrm{VI})$ reduction.

The possible U(VI) reduction through shaking is a probable reason for the identification of “poorly crystallized $\mathrm{UO}_{2(\mathrm{~s})}$ " reported by Abdelouas et al. ${ }^{[19]}$ It is not surprising that all other authors could not identify any uranium phases. ${ }^{[22]}$ About $5 \%$ of the initial amount of $\mathrm{Fe}^{0}$ was consumed under the experimental conditions of this work, which yielded to a Fe:U molar ratio of 154 in the mass of corrosion products (Tab. 3). That is $0.65 \%$ weight of not crystalline U(VI) entrapped in the mass of (partly amorphous) iron oxides, therefore non-detectable by X-ray diffraction for example. Because other authors have used larger amounts of $\mathrm{Fe}^{0}$ (solid to solution ratios up to $200 \mathrm{~g} / \mathrm{L}$ ) under shaken or stirred conditions, it can be assumed that 
more corrosion products were formed to entrap U(VI). Table 3 shows that under the experimental conditions of Abdelouas et al. ${ }^{[22]}, 0.06$ to $45 \% \mathrm{U}$ (molar Fe:U $=554$ to 1662 ) can be present in the mass of corrosion products when the $\mathrm{Fe}^{0}$ consumption varies from 5 to $15 \%$. For the same $\mathrm{Fe}^{0}$ consumptions, the percent $\mathrm{U}$ in the mass of corrosion products varies from 7.5 to $18.6 \%$ under the experimental conditions of Gu et al. ${ }^{[6]}$ This result shows that in both cases, sufficient amounts of corrosion products were present to entrap U(VI) in their matrix, making them inaccessible for desorption with $\mathrm{Na}_{2} \mathrm{CO}_{3}$. Note that although $\mathrm{Gu}$ et al. ${ }^{[6]}$ used Scanning Electron Microscopy (SEM), Energy Dispersive X-Ray Spectroscopy (EDX), and X-ray Fluorescence Spectroscopy (XFS) analyses to study the "reductive precipitation and coating of $\mathrm{U}$ on $\mathrm{Fe}^{0}$ surface" they could not identify any U(IV) phase. Furthermore, their XFS analysis was limited at showing that supposedly U(IV) remained at the surface of $\mathrm{Fe}^{0}$. As discussed above, $\mathrm{U}(\mathrm{VI})$ can be either accumulated at the surface of $\mathrm{Fe}^{0}$, precipitated for instance as schoepite $\left(\mathrm{UO}_{3} \cdot 2 \mathrm{H}_{2} \mathrm{O}\right)$, or entrapped in the mass of corrosion products. Speciation data on $\mathrm{U}(\mathrm{VI})$ removal from groundwater in $\mathrm{Fe}^{0}$ permeable reactive barriers at several sites support the formation of partially oxidized $\mathrm{U}$ deposited on $\mathrm{Fe}^{0}$ media. Matheson et al. ${ }^{[26]}$ reported approximately equal amounts of U(IV) $(\sim 55 \%)$ and U(VI) $(\sim 45 \%)$ in anoxic samples from Y-12 Plant in Oak Ridge (Tennessee) and $\sim 80 \% \mathrm{U}(\mathrm{VI})$ in oxic samples. At Bodo Canyon Site (Durango, Colorado) uranium was present nearly exclusively as U(VI). Table 4 presents uranium speciation in four field $\mathrm{Fe}^{0}$ reactive barriers (ref. 5) after service life of up to three years. These results clearly show that under actual field service conditions $\mathrm{U}(\mathrm{VI})$ reduction through $\mathrm{Fe}^{0}$ is not quantitative, even though, beside reduction through structural Fe(II), microbial activity might have contributed to U(VI) reduction. ${ }^{[64,65]}$

Another important fact in favor of U(VI) co-precipitation with aging corrosion products is given by Morrison et al. ${ }^{[22]}$, who conducted laboratory column experiments under anoxic conditions and could not accurately model their results according to reductive precipitation or $\mathrm{U}(\mathrm{VI})$ adsorption onto Fe(III) oxides. They stated that "while a reductive precipitation 
mechanism is not inconsistent with the results of the laboratory column experiment, the decrease in Eh in the bulk is suspect. Other mechanisms of $U$ removal such as adsorption on ferrous hydroxide or incorporation into mineral structures of ferrous hydroxide or magnetite are also possible". Note that they came to this statement because they used experimental conditions under which sorption onto iron oxides was inhibited (higher $\mathrm{pH}$, higher dissolved carbon). In fact, regardless from the nature of corrosion products (oxic or anoxic conditions) the present work has shown that the accessibility of the surface of $\mathrm{Fe}^{0}$ for $\mathrm{U}(\mathrm{VI})$ is almost impossible since corrosion products with higher affinity to U(VI) are formed on the surface of $\mathrm{Fe}^{0}$. Even though these corrosion products are porous, it is not expected that adsorbed U(VI) will quantitatively diffuse to the surface of $\mathrm{Fe}^{0}$. Ciu \& Saphiu ${ }^{[27]}$ reported that green rust on $\mathrm{Fe}^{0}$ was more efficient than $\mathrm{Fe}^{0}$ for $\mathrm{U}(\mathrm{VI})$ removal. This experimental result is supported by the Eh value for the solid state redox system [Fe(II)-Fe(III)] from White and Paterson $(-0.34$ to $-0.65 \mathrm{~V}),{ }^{[66]}$ possibly making structural $\mathrm{Fe}(\mathrm{II})$ a more stronger reducing agent than $\mathrm{Fe}^{0}\left[\mathrm{E}^{\circ}\right.$ for the redox system $\mathrm{Fe}(0)-\mathrm{Fe}(\mathrm{II}):-0.44 \mathrm{~V}]$.

Abdelouas et al. ${ }^{[19]}$ also used a solution of ETDA to avoid the formation of corrosion products and demonstrated the reductive precipitation as mechanism of $\mathrm{U}(\mathrm{VI})$ removal by $\mathrm{Fe}^{0}$. At the same time they did not mention the capacity of EDTA to form complexes with U(VI) and to accelerate iron corrosion. Iron corrosions yields to a complex mixture in which U(VI) will surely be entrapped without having any ability to reach the surface of $\mathrm{Fe}^{0}$ since $\mathrm{U}(\mathrm{VI})$ solubility may increase by EDTA complexation (e.g. ref. 67).

Further arguments for U(VI) co-precipitation with aging corrosion products were given from investigations of $\mathrm{U}(\mathrm{VI})$ removal from contaminated carbon steel surfaces. ${ }^{[53,55]}$ The surface of steel coupons was exposed to uranyl nitrate $\left[\mathrm{UO}_{2}\left(\mathrm{NO}_{3}\right)_{2}\right]$ solution. This operation led to the formation of a lightly corroded surface that was investigated using various spectroscopic techniques including X-ray Photoelectron Spectroscopy (XPS) and Scanning Electron Microscopy / Energy Dispersive Spectroscopy (SEM/EDS). The results showed that: (1) 
$\mathrm{U}(\mathrm{VI})$ tends to associate with lepidocrocite $[\mathrm{FeO}(\mathrm{OH})]$ and hydroxyl-rich areas on the surface of actively corroding steel; (2) U(VI) is well distributed within the upper micron of the corrosion layer and, (3) U(VI) is occluded by corrosion products as indicated by XPS. Similar to the present study, occluded U(VI) was not efficiently removed from the surface by a citric acid/hydrogen peroxide cleaning method, which successfully extracted $U$ in lightly corroded areas. $^{[55]}$

The investigation of the stability of U(VI) enclosed in the matrix of corrosion products is of major importance. EDTA will play a key role in this effort (assumption 2).

\subsection{Impact of iron oxide transformations on remediation efficiency}

It is important to investigate the impact of possible transformations of iron oxides on the remediation efficiency (long term stability of co-precipited uranium). The main possible transformation is dissolution (reductive, acidic, Eqs 10 and 12 in Tab. 1, or microbial). In nature, complexation of iron may also yield to U(VI) release (Eq. 11, Tab. 1).

To gain an impression on the fate of fixed U(VI) as corrosion products are transformed in the environment, a fixation experiment with $15 \mathrm{~g} / \mathrm{L} \mathrm{Fe}{ }^{0}$ and $20 \mathrm{mg} / \mathrm{L} \mathrm{U}(\mathrm{VI})$ was conducted for 60 days in tap water of the city of Jena (Thuringia, Germany); the achieved total fixation was > $99 \%$. Afterwards, calculated amounts of target solution were added to the vessels to achieve the final concentration of the transformation agents. In two sets of experiments the remobilization agent was pyrite of two different particle sizes (pyrite 1: $0.2-0.315 \mathrm{~mm}$ and pyrite 2: $0.315-0.63 \mathrm{~mm})$. The modification with pyrite aimed at simulating a local transformation that can lower the $\mathrm{pH}$, increasing the solubility of $\mathrm{U} \cdot{ }^{[25,51]}$ The other modification agents were: (a) $0.1 \mathrm{M} \mathrm{Na}_{2} \mathrm{CO}_{3}$ as reference desorption agent for laboratory investigations; (b) 0.01 M EDTA as an environmental relevant complexing agent; (c) $0.2 \mathrm{M}$ $\mathrm{HCl}$ as strong iron oxide digester (acidic dissolution); (d) $1.25 \% \mathrm{TiCl}_{3}$ as iron oxide reducer; (e) and a mixture of $0.01 \mathrm{M}$ EDTA $+1.25 \% \mathrm{TiCl}_{3}$. 
Figure 2 summarizes the results of $\mathrm{U}(\mathrm{VI})$ recovering $\left(\mathrm{P}_{\text {rec }}\right)$ by the enumerated agents for an experimental duration of 14 hours. As shown in Fig. 2, the two different particle sizes of the employed pyrite gave the same recovery rate of about $0.3 \%$ (the lowest) whereas the immobilization rate for $0.2 \mathrm{M} \mathrm{HCl}$ was the highest (almost $100 \%$ ), suggesting that destroying iron corrosion products will yield to $\mathrm{U}(\mathrm{VI})$ release into the environment. The recovery efficiency by EDTA was about one half of that of $\mathrm{Na}_{2} \mathrm{CO}_{3}(1.3 \%)$ for the experimental duration $(14 \mathrm{~h})$. However, it can be expected that the recovery efficiency for EDTA will increase with time since the kinetics and the extent of complexive dissolution depend on the crystallization grade of iron oxides. Therefore assumption 2 [favor of U(VI) release through EDTA] is verified confirming that reductive precipitation is not the major pathway of the $\mathrm{U}(\mathrm{VI})$ removal by $\mathrm{Fe}^{0}$. Finally, the recovery efficiency for both systems including $\mathrm{TiCl}_{3}$ was about $40 \%$ for the 14 hours. It should be emphasized that, even if the reduction of all Fe(III) contained in the available amount of corrosion products in each vessel is completed, the total recovery of $\mathrm{U}(\mathrm{VI})$ can not be expected since U(VI) also adsorbs onto Fe(II) colloids (ref. 16 and references therein).

This experiment shows that partial or total dissolution of some corrosion products in a reactive barrier will be associated with a release of sequestrated U(VI) into the environment. These experiments solely show qualitatively the fate of co-precipitated U(VI), as iron corrosion products are transformed. A quantitative characterization is almost impossible under the experimental conditions of this work because of the complicated interactions between $\mathrm{U}(\mathrm{VI})$ and $\mathrm{Fe}(\mathrm{II})$ and $\mathrm{Fe}(\mathrm{III})$ with increasing $\mathrm{pH} \cdot{ }^{[16]}$ However, intelligent concepts have to be developed to characterize the fate of co-precipitated $\mathrm{U}(\mathrm{VI})$ in the environment as physical, chemical or biological transformations of corrosion products occur.

\subsection{Identification of reaction products}

The reaction products were identified by XRD and SEM/EDX. 
X-ray diffraction spectra of corrosion products showed the presence of lepidocrocite, goethite, magnetite and/or maghemite and no single U phase. ${ }^{[25]}$ Amorphous compounds will not be seen in a XRD spectrum. Therefore, $\mathrm{U}$ species (IV or VI) present in the matrix of corrosion products may mostly be amorphous.

Scanning electron microscopy images of $\mathrm{Fe}^{0}$ coupon surface showed iron oxyhydroxides (termed as $\mathrm{FeO}$ in $\mathrm{Tab} .5$ ) on the surface, which is probably a layer of corrosion products. This external layer may physically shield other U containing corrosion product layers. ${ }^{[33,55]}$ Fig. 3 and Tab. 5 show that $\mathrm{U}$ is not uniformly distributed at the coupon surface. Rather, $\mathrm{U}$ tends to accumulate in corroded regions of the $\mathrm{Fe}^{0}$ surface $\left(\mathrm{P}_{3}\right.$ on Fig. 3). This observation is justified by the discussed larger affinity of corrosion products for $\mathrm{U}$ and corroborates $\mathrm{U}(\mathrm{VI})$ co-precipitation with iron corrosion products as a major removal mechanism. Thus, $\mathrm{U}$ containing regions are probably rusted regions of initial accelerated corrosion. Eng et al. ${ }^{[55]}$ observed by means of FTIR spectroscopy, that the uranyl ion is associated with iron corrosion products throughout the corrosion product layer formed on steel coupons. Their X-ray photoelectron spectroscopy results indicated a clear U(VI) incorporation within layers of corrosion products. This co-precipitation was more evident when a thin native oxide layer was generated in situ in the presence of $U$.

\section{Conclusions}

The interactions between $\mathrm{U}(\mathrm{VI}), \mathrm{Fe}^{0}$ and corrosion products in bulk $\mathrm{U}(\mathrm{VI}) / \mathrm{Fe}^{0} /$ additivesystems were characterized under reaction conditions pertinent to natural aquatic environments. The results provide no evidence for quantitative $\mathrm{U}(\mathrm{VI})$ reduction by $\mathrm{Fe}^{0}$ over the entire range of reaction conditions $(4<\mathrm{pH}<8)$. Rather, $\mathrm{U}(\mathrm{VI})$ removal by $\mathrm{Fe}^{0}$ is mostly caused by co-precipitation of adsorbed U(VI) with aging corrosion products. This concept is consistent with many experimental observations, for instance under conditions as retarding the availability of "free" corrosion products, respectively controlling their amount by $\mathrm{MnO}_{2}$ 
and modifying their reactivity by $\mathrm{FeS}_{2}$. Even under anoxic conditions, generated corrosion products have greater affinity for $\mathrm{U}$ than the bare $\mathrm{Fe}^{0}$ surface. Furthermore, these corrosion products are produced on the surface of $\mathrm{Fe}^{0}$. Therefore, it is very probable that the success of $\mathrm{Fe}^{0}$ in mitigating $\mathrm{U}(\mathrm{VI})$ in groundwater relies on a continuous generation of corrosion products which immobilize U(VI) by entrapping it in their matrix while aging. Field speciation data by Matheson et al. ${ }^{[26]}$ are consistent with U(VI) co-precipitation with iron corrosion products as major removal mechanism.

It is commonly assumed, that contaminant removal in $\mathrm{Fe}^{0}$ reactive barriers occurs principally under anoxic condition since molecular oxygen is consumed by iron corrosion in the barrier entrance zone. ${ }^{[42,68]}$ The present work has shown that generated corrosion products (aged or nascent) are capable of fixing $\mathrm{U}(\mathrm{VI})$. Thus, $\mathrm{U}(\mathrm{VI})$ can only migrate across the entrance zone (pre-treatment zone ${ }^{[68]}$ ) if the adsorptive capacity of actual available corrosion products is exhausted. Therefore, in an operative barrier both adsorption onto aged corrosion produc ts and co-precipitation with nascent iron oxides occur. Corrosion products form an active physical barrier avoiding the accessibility of the bare surface of $\mathrm{Fe}^{0}$ materials to U(VI). This assertion is supported by experimental evidences from Huang and Zhang ${ }^{[69]}$ who showed that dissolved oxygen is mostly consumed by $\mathrm{Fe}^{2+}$ rather than the surface of metallic iron $\left(\mathrm{Fe}^{0}\right)$. Therefore, reported $\mathrm{U}(\mathrm{VI})$ reduction in $\mathrm{Fe}^{0}$ barriers may mostly result from structural Fe(II) reaction, ${ }^{[8,9,27]}$ and/or microbial activity. ${ }^{[64,65]}$

With this study, the potential of bulk reactions with selected additives for providing mechanistic information on aqueous contaminant removal has been demonstrated. This applicable technique can be very useful to obtain qualitative information on $\mathrm{Fe}^{0}$ removal mechanisms for several contaminants; particularly for other radionuclides, metals and some organics which are known to interact with iron oxide. ${ }^{[47,70,71]}$ It is difficult from a practical standpoint to obtain quantitative information on processes or mechanisms because of the complex nature of corrosion products and the proportion of $U$ species in their matrix. It can be 
emphasized that co-precipitation or surface catalyzed reduction will govern the primary contaminant removal whenever strong interactions of the contaminant with corrosion products can be awaited. Selecting $\mathrm{Fe}^{0}$ for remediation of such contaminants is simplified because reactivity is a unique function of the material dissolution (iron corrosion), and not of the specific interaction of the contaminant with the material.

\section{Acknowledgments}

The used scrap iron $\left(\mathrm{Fe}^{0}\right)$ was kindly purchased by the branch of the MAZ (Metallaufbereitung Zwickau, Co) in Freiberg.

The main work was supported by the DFG-Graduiertenkolleg DFG-GK 272. Additive results were obtained in the DFG-funding DFG-Sa 501/15-1. 


\section{References}

[1] M. Junghans, C. Helling, Historical Mining, uranium tailings and waste disposal at one site: Can it be managed? A hydrogeological analysis, in Tailings and Mine Waste '98, Balkema, Rotterdam, 1998, pp. 117-126.

[2] A. Meinrath, P. Schneider, G. Meinrath, Uranium ores and depleted uranium in the environment - with a reference to uranium in the biosphere from the Erzgebirge / Sachsen, Germany, J. Environ. Rad. 64 (2003) 175-193.

[3] J.L. Jerden Jr., A.K. Sinha, Phosphate based immobilization of uranium in an oxidizing bedrock aquifer, Appl. Geochem. 18 (2003) 823-843.

[4] K.J. Cantrell, D.I. Kaplan, T.W. Wietsma, Zero-Valent Iron for the in situ Remediation of selected metals in Groundwater, J. Hazard. Mat. 42 (1995) 201-212.

[5] D. Naftz, S.J. Morrison, C.C. Fuller, J.A. Davis (eds), Handbook of groundwater remediation using permeable reactive barriers-Applications to radionuclides, trace metals, and nutrients, Academic Press, San Diego, 2002.

[6] B. Gu, L. Liang, M.J. Dickey, X. Yin, S. Dai, Reductive precipitation of uranium (VI) by zero-valent iron, Environ. Sci. Technol. 32 (1998) 3366-3373.

[7] J. Farrell, W.D. Bostick, R.J. Jarabeck, J.N. Fiedor, Uranium removal from ground water using zero valent iron media, Ground Water 34 (1999) 618-624.

[8] L. Charlet, E. Silvester, E. Liger, N-compound reduction and actinide immobilisation in surficial fluids by $\mathrm{Fe}(\mathrm{II})$ : the surface $\mathrm{Fe}^{\mathrm{III}} \mathrm{OFe}^{\mathrm{II}} \mathrm{OH}^{\circ}$ species, as major reductant, Chem. Geol. 151 (1998) 85-93.

[9] E. Liger, L. Charlet, P. van Cappellen, Surface catalysis of uranium(VI) reduction by iron (II), Geochim. Cosmochim. Acta 63 (1999) 2939-2955. 
[10] J.E. O'Loughlin, D.S. Kelly, E.R. Cook, R. Csencsits, M.K. Kemner, Reduction of Uranium(VI) by Mixed Iron(II)/Iron(III) Hydroxide (Green Rust): Formation of $\mathrm{UO}_{2}$ Nanoparticles, Environ. Sci. Technol 37 (2003) 721-727.

[11] T. Behrends, P. Van Cappellen, Competition between enzymatic and abiotic reduction of uranium(VI) under iron reducing conditions, Chem. Geol. 220 (2005) 315-327.

[12] B.-H. Jeon, B.A. Dempsey, W.D. Burgos, M.O. Barnett, E.E. Roden, Chemical reduction of $\mathrm{U}(\mathrm{VI})$ by $\mathrm{Fe}(\mathrm{II})$ at the solid-water interface using natural and synthetic $\mathrm{Fe}(\mathrm{III})$ oxides. Environ. Sci. Technol. 39 (2005) 5642-5649.

[13] J.D. Istok, J.M. Senko, L.R. Krumholz, D. Watson, M.A. Bogle, A. Peacock, Y.-Y. Chang, D.C. White, In Situ Bioreduction of Technetium and Uranium in a NitrateContaminated Aquifer, Environ. Sci. Technol. 38 (2004) 468-475.

[14] G.K. Robinson, R. Ganesh, G.D. Reed, Impact of organic ligands on uranium removal during anaerobic biological treatment, Wat. Sci. Technol. 37 (1998) 73-80.

[15] Y. Suzuki, S.D. Kelly, K.M. Kemner, J.F. Banfield, Direct microbial reduction and subsequent preservation of uranium in natural near-surface sediment. Appl. Environ. Microbiol. 71 (2005) 1790-1797.

[16] C. Noubactep, G. Meinrath, P. Dietrich, B.J. Merkel, Mitigating Uranium in Ground Water: Prospects and Limitations, Environ. Sci. Technol. 37 (2003) 4304-4308.

[17] F.G. Simon, C. Segebade, M. Hedrich, Behaviour of uranium in iron-bearing permeable reactive barriers: Investigation using ${ }^{237} \mathrm{U}$ as a radiotracer, Sci Total Environ. 307 (2003) $231-238$.

[18] Y. Wang, K. Salvage, Immobilization of uranium in the presence of $\mathrm{Fe}^{0}(\mathrm{~s})$ : Model development and simulation of contrasting experimental conditions. Appl. Geochem. 20 (2005) 1268-1283. 
[19] A. Abdelouas, W. Lutze, H.E. Nutall, W. Gong, Réduction de l'U(VI) par le fer métallique: application à la dépollution des eaux, C. R. Acad. Sci. Paris / Earth \& Planet. Sci. 328 (1999) 315-319.

[20] B. Gu, D.B. Watson, D.H. Phillips, L. Liang, Biogeochemical, Mineralogical, and Hydrological Characteristics of an Iron Reactive Barrier Used for Treatment of Uranium and Nitrate, in Handbook of groundwater remediation using permeable reactive barriers: Applications to radionuclides, trace metals, and nutrients. D. Naftz, S.J. Morrison, C.C. Fuller, J.A. Davis (eds), 2002, Academic Press, San Diego, Calif., pp. 305-342.

[21] S. Morrison, Performance Evaluation of a Permeable Reactive Barrier Using Reaction Products as Tracers, Environ. Sci. Technol. 37 (2003) 2302-2309.

[22] S.J. Morrison, R.D. Metzler, E.C. Carpenter, Uranium Precipitation in a Permeable Reactive Barrier by Progressive Irreversible Dissolution of Zerovalent Iron, Environ. Sci. Technol. 35 (2001) 385-390.

[23] E. Papastavros, P.J. Shea, M.A. Langell, Oxygen, carbon, and sulfur segregation in annealed and unannealed zerovalent iron substrates, Langmuir 20 (2004) 11509-11516.

[24] Y. Roh, S.Y. Lees, M.P. Elless, K.-S. Cho, Electro-enhanced remediation of radionuclides-contaminated groundwater using zero-valent iron, J. Environ. Sci. Health A35 (2000) 1043-1059.

[25] C. Noubactep, Investigations for the passive in-situ Immobilization of Uranium (VI) from Water (in German). Dissertation, TU Bergakademie Freiberg, Wiss. Mitt. Institut für Geologie der TU Bergakademie Freiberg, 21 (2003) 140 pp, ISSN1433-1284.

[26] L.J. Matheson, W.C. Goldberg, W.D. Bostick, L. Harris, Analysis of UraniumContaminated Zero- Valent Iron Media Sampled From Permeable Reactive Barriers Installed at U.S. Department of Energy Sites in Oak Ridge, Tennessee and Durango, Colorado, USA, in Handbook of groundwater remediation using permeable reactive barriers: Applications to radionuclides, trace metals, and nutrients. D. Naftz, S.J. 
Morrison, C.C. Fuller, J.A. Davis (eds.), 2002, Academic Press, San Diego, Calif., pp. $343-367$.

[27] D. Cui, K. Spahiu, The reduction of U(VI) on corroded iron under anoxic conditions, Radiochim. Acta 90 (2002) 623-628.

[28] S.R. Qiu, H.-F. Lai, M.J. Roberson, M.L. Hunt, C. Amrhein, L.C. Giancarlo, G.W. Flynn, J.A. Yarmoff, Removal of contaminants from aqueous solution by reaction with iron surfaces, Langmuir 16 (2000) 2230-2236.

[29] W.D. Bostick, R.J. Jarabek, J.N. Fiedor, J. Farrell, R. Helferich, Zero-valent iron and metal oxides for the removal of soluble regulated metals in contaminated ground waters at a DOE Site, in International Containment Technology Conference Proceedings February 9-12, St. Petersburg, Florida, USA, 1997, pp. 767-773.

[30] J.N. Fiedor, W.D. Bostick, R.J. Jarabek, J. Farrel, Understanding the mechanism, of uranium removal from groundwater by zero-valent iron using X-ray photoelectron spectroscopy, Environ. Sci. Technol. 32 (1998) 1466-1473.

[31] G.C. Allen, T.B. Scott, D.F. Lee, M.G. Randall, The extraction of uranium from groundwaters on iron surfaces, Phil. Mag. Lett. 84 (2004) 691-696.

[32] T.B. Scott, G.C. Allen, P.J. Heard, A.C. Lewis, D.F. Lee, The extraction of uranium from groundwaters on iron surfaces, Proc. Math. Phys. Eng. Sci. 461 (2005) 1247-1259.

[33] J.G. Bain, K.U. Mayer, D.W. Blowes, E. O. Frind, J.W.H. Molson, R. Kahnt, U. Jenk, Modelling the closure-related geochemical evolution of groundwater at a former uranium mine, J. Cont. Hydrol.52 (2001) 109-135.

[34] USEPA. Permeable Reactive Barrier Technologies for Contaminant Remediation. EPA 600-R-98-125. September 1998.

[35] R.K. Sani, B.M. Peyton, A. Dohnalkova, J.E. Amonette, Reoxidation of Reduced Uranium with Iron(III) (Hydr)Oxides under Sulfate-Reducing Conditions, Environ. Sci. Technol. 39 (2005) 2059-2066. 
[36] C. Noubactep, M. Fall, G. Meinrath, B. Merkel, A Simple Method to Select Zero Valent Iron Material for Groundwater Remediation, in 57th Canadian Geotechnical Conference/5th Joint CGS/IAH-CNC Conference 2004, pp. 6-13 (CGRG Québec City, PG).

[37] C. Noubactep, G. Meinrath, P. Dietrich, M. Sauter, B. Merkel, Testing Suitability of Zerovalent Iron Materials for Reactive Walls, Environ. Chem. 2 (2005) 71-76.

[38] J.S. Arey, J.C. Seaman, M.P. Bertsch, Immobilisation of uranium in contaminated sediments by hydroxyapatite addition, Environ. Sci. Technol. 33 (1999) 337-342.

[39] F.G. Simon, V. Biermann, C. Segebade, M. Hedrich, Behaviour of uranium in hydroxyapatite-bearing permeable reactive barriers: Investigation using ${ }^{237} \mathrm{U}$ as a radioindicator, Sci Total Environ. 326 (2004) 249-256.

[40] S.B. Savvin, Analytical use of Arsenazo III: Determination of thorium, zirconium, uranium and rare earth elements, Talanta 8 (1961) 673-685.

[41] G. Meinrath, P. Volke, C. Helling, E.G. Dudel, B.J. Merkel, Determination and Interpretation of environmental water samples contaminated by uranium mining activities. Fresenius J. Anal. Chem. 364 (1999) 191-202.

[42] R.M. Powell, P.D. Powell, Iron Metal for Subsurface Remediation, in The Encyclopedia of Environmental Analysis and Remediation. R.A. Myers (Ed). John Wiley \& Sons, Inc., New York. 8 (1998) 4729-4761.

[43] G.R. Ford, Rates of Hydrous Ferric Oxide Crystallization and the Influence on Coprecipitated Arsenate, Environ. Sci. Technol. 36 (2002) 2459-2463.

[44] G. Heron, C. Crouzet, C.M.A. Bourg, H.T. Christensen, Oxidation Capacity of Aquifer Sediments, Environ. Sci. Technol. 28 (1994) 1698-1705.

[45] B. Gu, T.L. Mehlhorn, L. Liang, J.F. McCarthy, Competitive adsorption, displacement, and transport of organic matter on iron oxide: I. Competitive adsorption, Geochim. Cosmochim. Acta 60 (1996) 1943-1950. 
[46] C. Noubactep, P. Volke, G. Meinrath, B. Merkel, Mitigation of Uranium in Effluents by Zero Valent Iron: The Role of Iron Corrosion Products, paper presented at the ICEM'01 Conference, September 30 - October 4, 2001, in Brugge - Belgium. published on CDROM, December, 2001, Session 51-2, 2001, Abstract \#364.

[47] C.H. Ho, N.H. Miller, Adsorption of uranyl species from bicarbonate solution onto hematite particles, J. Colloid Interf. Sci. 110 (1986) 165-171.

[48] Ch.- K. Hsi, D. Langmuir, Adsorption of uranyl onto ferric oxyhydroxides: application of the surface complexation site-binding model, Geochim. Cosmochim. Acta 49 (1985) $1931-1941$.

[49] D. Langmuir, Uranium solution-mineral equilibria at low temperatures with application to sedimentary ore deposits, Geochim. Cosmochim. Acta 42 (1978) 547-569.

[50] C. Noubactep, G. Meinrath, P. Volke, H-J. Peter, P. Dietrich, B. Merkel, Understanding the mechanism of the uranium Mitigation by zero valent iron in effluents, in. Wiss. Mitt. Institut für Geologie der TU Bergakademie Freiberg, 18 (2001), 37-44. ISSN 14331284.

[51] C. Noubactep, G. Meinrath, P. Volke, H.-J. Peter, P. Dietrich, B. Merkel, Mechanism of uranium fixation by zero valent iron: the importance of co-precipitation, in Uranium in the Aquatic Environment. Springer, Berlin, 2002, pp. 577-586.

[52] J.R. Rustad, K.M. Rosso, A.R. Felmy, Molecular dynamics investigation of ferrousferric electron transfer in a hydrolyzing aqueous solution: Calculation of the $\mathrm{pH}$ dependence of the diabatic transfer barrier and the potential of mean force, J. Chem. Phys. 120 (2004) 7606-7615.

[53] C. J. Dodge, A. J. Francis, J.B. Gillow, G.P. Halada, C. Eng, C.R. Clayton, Association of Uranium with Iron Oxides Typically Formed on Corroding Steel Surfaces, Environ. Sci. Technol.36 (2002) 3504-3511. 
[54] M.C. Duff, J.U. Coughlin, B.D. Hunter, Uranium co-precipitation with iron oxide minerals, Geochim. Cosmochim. Acta 66 (2002) 3533-3547.

[55] C.W. Eng, G. P. Halada, J.A. Francis, J.C. Dodge, J. Gillow, Uranium association with corroding carbon steel surfaces, J. Surf. Interface Anal.35 (2003) 525-535.

[56] G. Meinrath, T. Kimura, Carbonate Complexation of the Uranyl(VI) Ion, J. Alloy Com. 202 (1993) 89-93.

[57] H. Sontheimer, J.C. Crittenden, R.S. Summers, Activated carbon for water treatment. 2nd Edition. Karlsruhe. DVGW-Forschungsstelle, Germany. 1988.

[58] V. Metz, J. Ganor, Stirring effect on kaolinite dissolution rate. Geochim. Cosmochim. Acta 65 (2001) 3475-3490.

[59] H. Klas, H. Steinrath, Die Korrosion des Eisens und ihre Verhüttung. Stahleisen, Düsseldorf, 1974.

[60] W.H.J. Vernon, Controlling factors in atmospheric and immersed corrosion, J. Sci. Instrum. 22 (1945) 226-230.

[61] G.W. Whitman, R.P. Russel, V. Altieri, Effect of hydrogen-ion concentration on the submerged corrosion of steel, J. Indust. Eng. Chem. 16 (1924) 665-670.

[62] E. R. Wilson, The mechanism of the corrosion of iron and steel in natural waters and the calculation of specific rates of corrosion, Indust. Eng. Chem. 15 (1923) 127-133.

[63] S. Nesic, M. Nordsveen, R. Nyborg, A. Stangeland, A Mechanistic Model for Carbon Dioxide Corrosion of Mild Steel in the Presence of Protective Iron Carbonate FilmsPart 2: A Numerical Experiment, Corrosion 59 (2003) 489-497.

[64] D.R. Lovley, E.J.P. Phillips, Bioremediation of uranium contamination with enzymatic uranium reduction, Environ. Sci. Technol. 26 (1992) 2228-2234.

[65] J.C. Renshaw, L.J.C. Butchins, F.R. Livens, I. May, J.M. Charnock, J.R. Lloyd, Bioreduction of Uranium: Environmental Implications of a Pentavalent Intermediate. Environ. Sci. Technol. 39 (2005) 5657-5660. 
[66] A. F. White, M. L. Paterson, Reduction of aqueous transition metal species on the surface of Fe(II)-containing oxides, Geochim. Cosmochim. Acta 60 (1996) 3799-3814.

[67] S. Rihs, N.C. Sturchio, K. Orlandini, L. Cheng, H. Teng, P. Fenter, M.J. Bedzyk, Interaction of Uranyl with Calcite in the Presence of EDTA, Environ. Sci. Technol. 38 (2004) 5078-5086.

[68] J.F. Kenneke, S.C. McCutcheon, Use of pretreatment zones and zerovalent iron for the remediation of chloroalkenes in an oxic aquifer. Environ. Sci. Technol. 37 (2003) 2829_ 2835.

[69] Y.H. Huang, T.C. Zhang, Effects of dissolved oxygen on formation of corrosion products and concomitant oxygen and nitrate reduction in zero-valent iron systems with or without aqueous $\mathrm{Fe}^{2+}$, Wat. Res. 39 (2005) 1751-1760.

[70] B.R. Coughlin, A.T. Stone, Nonreversible Adsorption of Divalent Metal Ions (MnII, CoII, NiII, CuII, and PbII) onto Goethite: Effects of Acidification, FeII Addition, and Picolinic Acid Addition, Environ. Sci. Technol. 29 (1995) 2445-2455.

[71] A.T. Kan, G. Fu, M.A. Hunter, M.B. Tomson, Irreversible adsorption of napthalene and tetrachlorobiphenyl to Lula and surrogate sediments, Environ. Sci. Technol. 31 (1997) $2176-2185$. 


\section{Figures Captions}

Figure 1: Comparison of the kinetics of uranium removal with water works sludge (WWS), apatite and elemental iron $\left(\mathrm{Fe}^{0}\right)$. All experiments were applied in triplicate, error bars give standard deviations. The used particle size of the material was 1.6-2.0 $\mathrm{mm}$. The used apatite contains around $36 \% \mathrm{P}$ and was not further characterized. The represented lines are not fitting functions, they just joint the points to facilitate visualization.

Figure 2: Percent recovery $\mathrm{P}_{\text {rec }}$ of uranium from $\mathrm{Fe}^{0}$ and corrosion products by different agents for 14 hours. All experiments were applied in triplicate. $\mathrm{P}_{\mathrm{rec}}=0.3 \%$ corresponds to a concentration of $60 \mu \mathrm{g} / \mathrm{L}$ (> $30 \mu \mathrm{g} / \mathrm{L}, \mathrm{MCL}$ of the US EPA). Error bars give standard deviations. The percent recovery is given in/on the bars.

Figure 3: Scanning electron microscopy image of $\mathrm{Fe}^{0}$ coupon after three months reaction time with $20 \mathrm{mg} / \mathrm{L}$ U(VI). The mineralogical composition of selected points (P1, P2 and P3) is shown in Tab. 5. 
Table 1: Possible reaction pathways for $\mathrm{U}$ removal from the aqueous phase by $\mathrm{Fe}^{0}$ under the experimental conditions and their reversibility under natural conditions.

\begin{tabular}{|c|c|c|c|}
\hline Mechanism & Reaction & Reversibility & Eq. \\
\hline Precipitation: & $\mathrm{UO}_{2}{ }^{2+}{ }_{(\mathrm{aq})}+2 \mathrm{OH}^{-} \Leftrightarrow \mathrm{UO}_{3} \cdot 2 \mathrm{H}_{2} \mathrm{O}_{(\mathrm{s})}$ & Reversible & (i) \\
\hline Sorption: & $\mathrm{UO}_{2}^{2+}+\mathrm{S}_{\text {(sorption site) }} \Leftrightarrow \mathrm{S}-\mathrm{UO}_{2}{ }^{2+}$ & Reversible & (ii) \\
\hline $\mathrm{Fe}^{0}$ Reduction: & $\mathrm{Fe}^{0}+\mathrm{UO}_{2}^{2+}{ }_{(\mathrm{aq})} \Rightarrow \mathrm{UO}_{2}(\mathrm{~s})+\mathrm{Fe}^{2+}$ & Irreversible & (iii) \\
\hline $\mathrm{Fe}_{(\mathrm{s})}^{2+}$ Reduction: & $\mathrm{UO}_{2}^{2+}+2 \mathrm{Fe}_{(\mathrm{s})}^{2+} \Rightarrow \mathrm{UO}_{2}+2 \mathrm{Fe}_{(\mathrm{s})}^{3+}$ & Irreversible & (iv) \\
\hline
\end{tabular}

Table 2: Some relevant reactions for the elucidation of the mechanism of U(VI) fixation by $\mathrm{Fe}^{0}$.

\begin{tabular}{|c|c|c|c|}
\hline Reaction equation & & $\log K$ & Eq. \\
\hline $\mathrm{UO}_{2}^{2+}+\mathrm{Fe}^{0}$ & $\Leftrightarrow \mathrm{UO}_{2(\mathrm{~s})}+\mathrm{Fe}^{2+}$ & - & (1) \\
\hline $\mathrm{UO}_{2}^{2+}{ }_{(\text {aq or s })_{-}^{-}}+2 \mathrm{Fe}^{2+}(\mathrm{s})$ & $\Leftrightarrow \mathrm{UO}_{2(\mathrm{~s})}+2 \mathrm{Fe}^{3+}(\mathrm{s})$ & - & (2) \\
\hline $\mathrm{UO}_{2}^{2+}+\mathrm{H}_{2(\mathrm{~g})}$ & $\Leftrightarrow \mathrm{UO}_{2(\mathrm{~s})}+2 \mathrm{H}^{+}$ & - & (3) \\
\hline $\mathrm{UO}_{2(\mathrm{~s})}+2 \mathrm{Fe}^{3+}{ }_{(\mathrm{aq})}$ & $\Leftrightarrow \mathrm{UO}_{2}^{2+}{ }_{(\mathrm{aq} \text { or } \mathrm{s})}+2 \mathrm{Fe}^{2+}{ }_{(\mathrm{aq})}$ & $11.96^{*}$ & (4) \\
\hline $2 \mathrm{Fe}^{2+}+1 / 2 \mathrm{O}_{2}+5 \mathrm{H}_{2} \mathrm{O}$ & $\Leftrightarrow 2 \mathrm{Fe}(\mathrm{OH})_{3}+4 \mathrm{H}^{+}$ & $7.20^{*}$ & $(5)$ \\
\hline $\mathrm{Fe}(\mathrm{OH})_{3}$ & $\Leftrightarrow \alpha-, \beta-\mathrm{FeOOH}, \mathrm{Fe}_{3} \mathrm{O}_{4}, \mathrm{Fe}_{2} \mathrm{O}_{3}$ & - & (6) \\
\hline $\mathrm{FeS}_{2}+14 \mathrm{Fe}_{(\mathrm{aq})}^{3+}+8 \mathrm{H}_{2} \mathrm{O}$ & $\Leftrightarrow 15 \mathrm{Fe}^{2+}+2 \mathrm{SO}_{4}{ }^{2-}+16 \mathrm{H}^{+}$ & $16.78^{*}$ & (7) \\
\hline $\mathrm{FeS}_{2}+7 \mathrm{UO}_{2}^{2+}+8 \mathrm{H}_{2} \mathrm{O}$ & $\Leftrightarrow \mathrm{Fe}^{2+}+7 \mathrm{UO}_{2(\mathrm{~s})}+2 \mathrm{SO}_{4}{ }^{2-}+16 \mathrm{H}^{+}$ & $-20.91^{*}$ & (8) \\
\hline $\mathrm{Fe}^{2+}{ }_{(\mathrm{aq})}+\mathrm{MnO}_{2}+2 \mathrm{H}_{2} \mathrm{O}$ & $\Leftrightarrow \mathrm{FeOOH}+\mathrm{MnOOH}+2 \mathrm{H}^{+}$ & - & (9) \\
\hline $\mathrm{FeOOH}+\mathrm{Ti}^{3+}+\mathrm{H}^{+}$ & $\Leftrightarrow \mathrm{Fe}^{2+}+2 \mathrm{OH}^{-}+\mathrm{Ti}^{4+}$ & - & (10) \\
\hline $\mathrm{FeOOH}+\mathrm{EDTA}+3 \mathrm{H}^{+}$ & $\Leftrightarrow \mathrm{Fe}(\mathrm{EDTA})^{3+}+2 \mathrm{H}_{2} \mathrm{O}$ & - & (11) \\
\hline $\mathrm{FeOOH}+3 \mathrm{H}^{+}$ & $\Leftrightarrow \mathrm{Fe}^{3+}+2 \mathrm{H}_{2} \mathrm{O}$ & - & (12) \\
\hline
\end{tabular}


Table 3: Comparison of the molar Fe: $\mathrm{U}$ ratios $(\mathrm{Fe}: \mathrm{U})_{\mathrm{x}}$ in the mass of corrosion products under the experimental conditions of two references and those of this work. In $(\mathrm{Fe}: \mathrm{U})_{\mathrm{x}}, \mathrm{x}$ represents the percent consumption of the initial amount of $\mathrm{Fe}^{0}$ (5\% in this work).

\begin{tabular}{llllllll}
\hline Reference & $\mathbf{p H}_{\mathbf{0}}$ & $\mathbf{F e}^{\mathbf{0}}$ & {$\left[\mathrm{U}_{\mathbf{0}}\right.$} & $\mathbf{V}_{\mathbf{0}}$ & $(\mathrm{Fe}: \mathrm{U})_{\mathbf{5}}$ & $(\mathbf{F e}: \mathrm{U})_{\mathbf{1 0}}$ & $(\mathrm{Fe}: \mathrm{U})_{\mathbf{1 5}}$ \\
& & $(\mathrm{g} / \mathrm{L})$ & $(\mathbf{m g} / \mathbf{L})$ & $(\mathbf{m L})$ & & & \\
\hline Gu et al. (1998) & 5.00 & 200 & 10000 & 10 & 4.1 & 8.2 & 12.4 \\
Abdelouas et al. (1999) & 7.00 & 25 & 9.3 & 40 & 554 & 1108 & 1662 \\
& - & 25 & 4285 & 40 & 1.2 & 2.4 & 3.6 \\
this work & 7.20 & 15 & 20 & 20 & 154 & - & - \\
\hline
\end{tabular}


Table 4: Published uranium speciation data from field $\mathrm{Fe}^{0}$ reactive barriers (from ref. 5).

\begin{tabular}{|c|c|c|c|}
\hline Site location & service life & uranium speciation & reference \\
\hline Y-12 Plant Oak Ridge; & & mostly U(VI) & \\
\hline Tennessee & $\sim 3$ years & & Gu et al. 2002 \\
\hline Y-12 Plant Oak Ridge; & & $\sim 55 \%$ U(IV) & \\
\hline Tennessee & 1.2 years & $\sim 45 \% \mathrm{U}(\mathrm{VI})$ & Matheson et al. 2002 \\
\hline \multicolumn{4}{|l|}{ Bodo Canyon Site; } \\
\hline Durango - Colorado & 3 years & $\sim 100 \% . \mathrm{U}(\mathrm{VI})$ & Matheson et al. 2002 \\
\hline \multicolumn{4}{|l|}{ Former Mill Site; } \\
\hline Manticello Utah & 3 years & $\mathrm{U}(\mathrm{IV})$ and $\mathrm{U}(\mathrm{VI})$ & Morrison et al. 2002 \\
\hline
\end{tabular}

Table 5: Mineralogical distribution of reaction products on the surface of $\mathrm{Fe}^{0}$ coupon as observed at three selected points (Fig. 5) by means of energy-dispersive X-ray (EDX).

\begin{tabular}{lcccccccc}
\hline Sample & $\mathbf{A l}_{\mathbf{2}} \mathbf{O}_{3}$ & $\mathrm{SiO}_{2}$ & $\mathbf{C r}_{\mathbf{2}} \mathbf{O}_{3}$ & $\mathbf{M n O}$ & $\mathbf{F e O}$ & $\mathrm{MgO}$ & $\mathbf{C a O}$ & $\mathbf{U}$ \\
\hline $\mathbf{P}_{\mathbf{1}}$ & 0.09 & 4.45 & 0.20 & 0.48 & 94.48 & 0.09 & 0.04 & 0.00 \\
$\mathbf{P}_{\mathbf{2}}$ & 0.02 & 1.99 & 0.09 & 1.46 & 96.11 & 0.16 & 0.16 & 0.00 \\
$\mathbf{P}_{3}$ & 0.24 & 3.44 & 0.00 & 0.36 & 95.73 & 0.00 & 0.02 & 0.20 \\
\hline
\end{tabular}


Figure 1

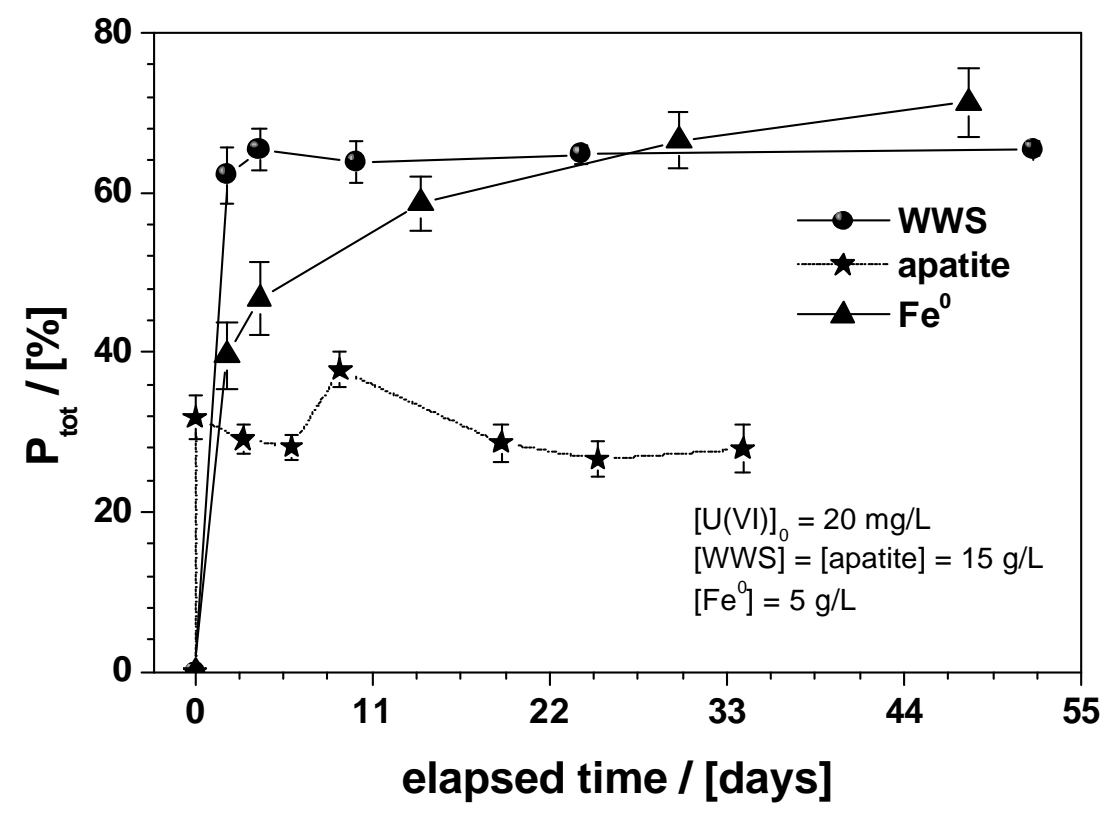


Figure 2

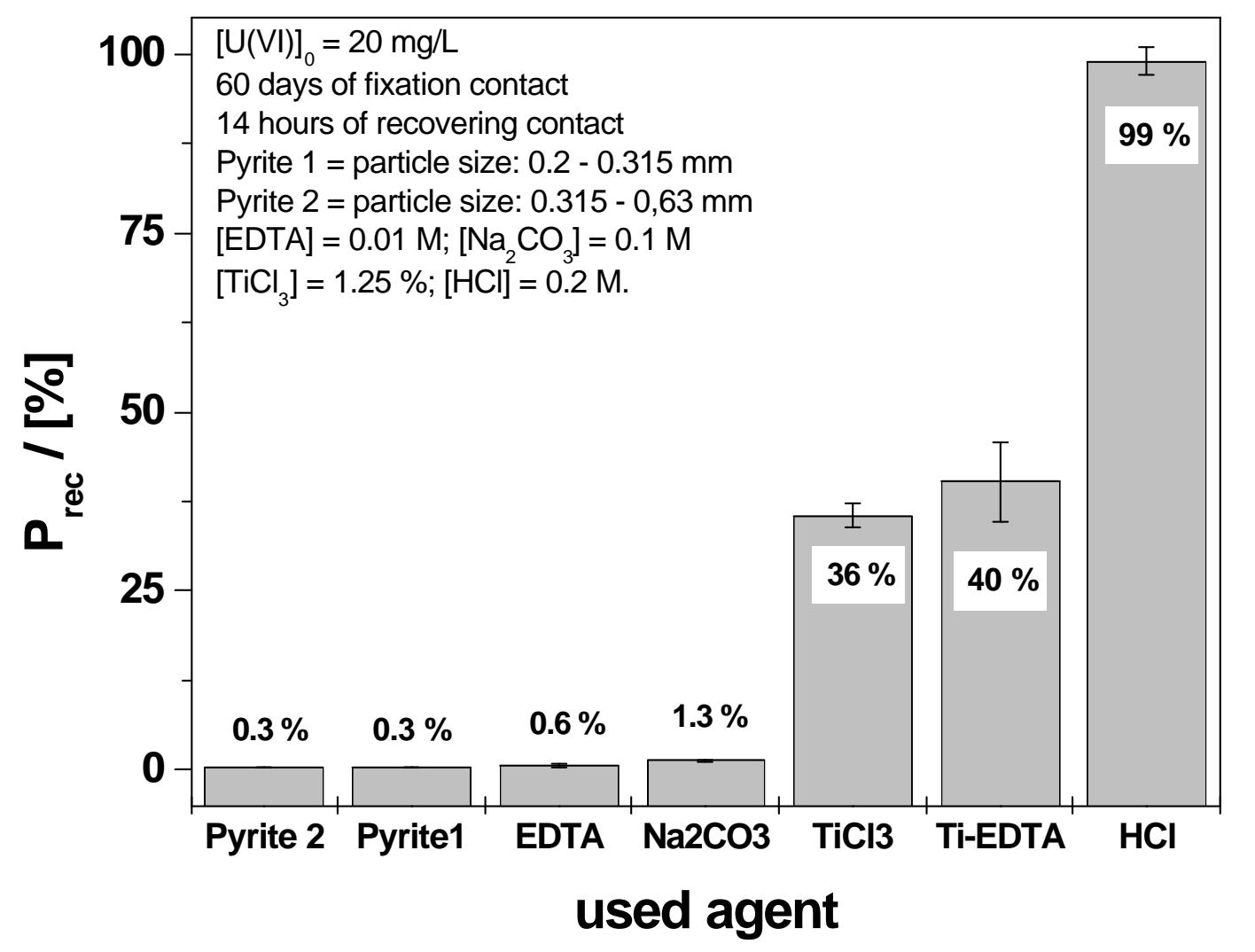


Figure 3

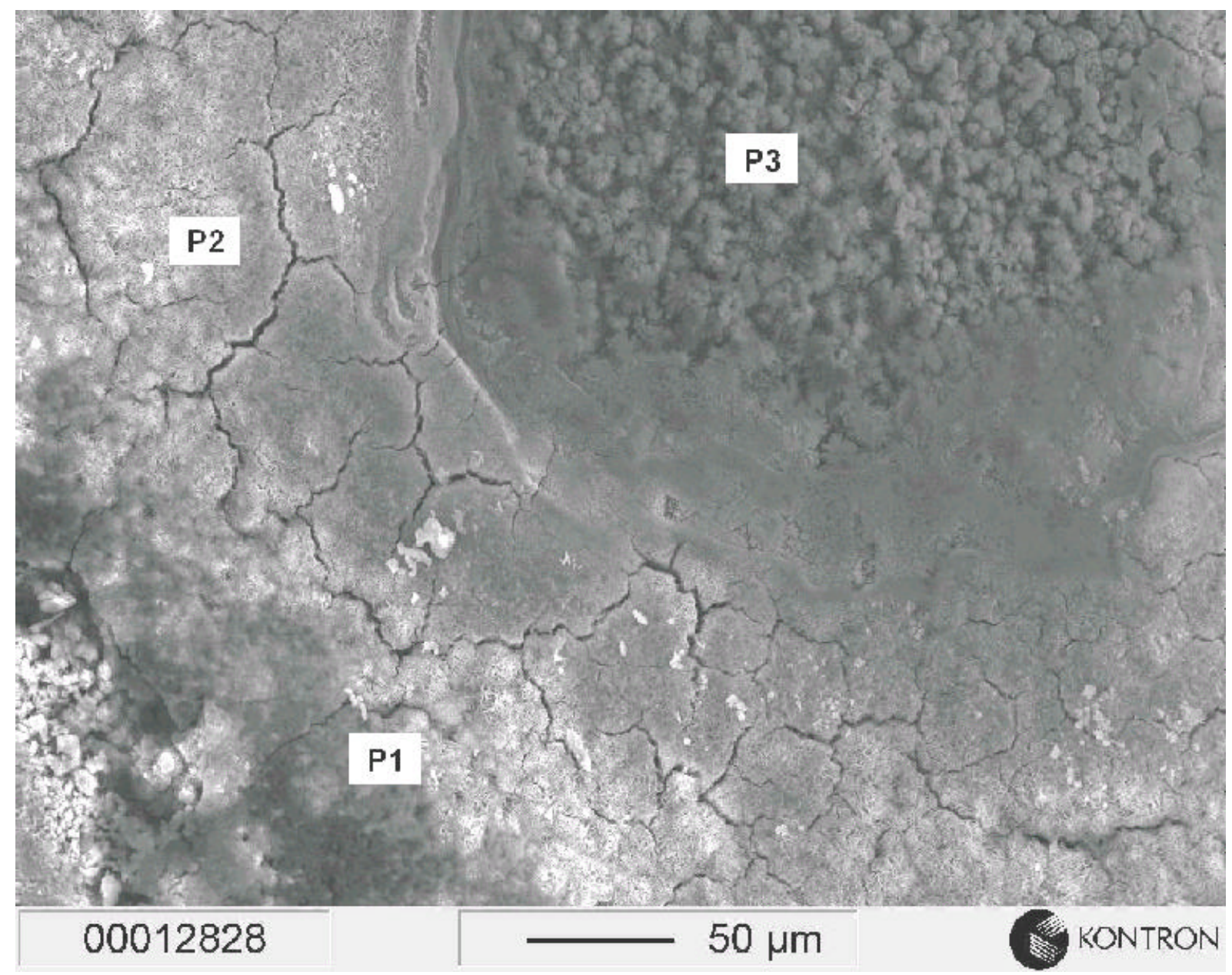

